\title{
Distribution and morphological diversity of Astyanax rivularis Lütken, 1874 (Teleostei Characiformes) in the upper São Francisco River basin, Brazil
}

\author{
Rubens Pasa*, Caroliny Helena Moreira Fernandes, Renan Rodrigues Rocha \& Karine Frehner Kavalco \\ Laboratory of Ecological and Evolutionary Genetics, Federal University of Viçosa, Campus Rio Paranaíba. Rout BR 354, \\ km 310. 38810-000, PO Box 22, Rio Paranaíba, Minas Gerais, Brazil \\ *Corresponding author, e-mail: rpasa@ufv.br
}

ABSTRACT

Astyanax S.F. Baird et Girard, 1854 (Teleostei Characiformes) is one of the most well characterized of the neotropical ichthyofauna and is composed of fish with great ability to adapt to different environmental conditions and a wide spectrum of interaction in fish assemblages due to its structure and population density. This study presents the geographical distribution and morphological diversity of Astyanax rivularis Lütken, 1874, a fish historically complex and extremely diverse, in tributary streams of the left side of upper São Francisco River.

KEY WORDS Brazil; Neotropical Fish; Brazilian Savannah; Characidae.

Received 13.07.2019; accepted 22.10.2019; published online 28.10.2019

\section{INTRODUCTION}

Although the genus Astyanax Baird et Girard, 1854 is one of the most well characterized of the neotropical ichthyofauna, perhaps for its easy capture, certain biological characteristics of this fish indicate that further studies are necessary for better understanding its natural history. The formation of structured populations, combined with evolutionary processes, such as vicariance, certainly plays a key role in the diversity of the group, which emerges as a genus where allopatric speciation has probably occurred. However, it is very difficult to determine specific limits in the group. There are at least four groups of cryptic species proposed in the genus, where different taxa with diagnostic characters (usually chromosomal) are observed sharing the same specific denomination. These cases involve both morphological characteristics and chromosomal or molecular aspects.
The genus Astyanax is composed of fish with great ability to adapt to different environmental conditions and a wide spectrum of interaction in fish assemblages due to its structure and population density (Orsi et al., 2004). This is demonstrated by the wide geographical distribution of the group, which covers almost the entire neotropical region (Eigenmann, 1921) and comprises about 150 species distributed from southern United States to northern Argentina (Eschmeyer \& Fong, 2019).

Garutti (1995) states that the genus Astyanax has a structured distribution, which suggests a high level of endemism: even within a single basin, there are multiple forms with relatively restricted geographic distribution. Therefore, it is assumed that Astyanax do not form a uniform group, but present variations between populations, probably because this group inhabits many different microenvironments (Garutti \& Britski, 2000). However, they are more successful in the best preserved habitats (Orsi 
et al., 2004). In fact, it is observed that populations of Astyanax present genetic structure along a river (Moysés \& Almeida-Toledo, 2002; Prioli et al., 2002; Leuzzi et al., 2004; Paiva et al., 2006).

Astyanax rivularis (Fig. 1) was described by Lütken (1874) as Tetragonopterus rivularis from the collections of Reinhardt of the mid-nineteenth century in the Velhas River, a major tributary of the São Francisco River. Later, it was considered a subspecies of $A$. scabripinnis Jenyns, 1842: A. scabri- pinnis rivularis (Eigenmnann, 1921). Chromosomal and morphometric characteristics led Moreira-Filho \& Bertollo (1989) to conclude that A. scabripinnis is a species complex of which about 14 are currently recognized (Bertaco \& Lucena, 2006). According to the "Catalog of Fishes" (Eschmeyer \& Fong, 2019), A. rivularis Lütken, 1874 (Characidae Stethaprioninae) is currently accepted as a valid species with distribution in São Francisco River basin.

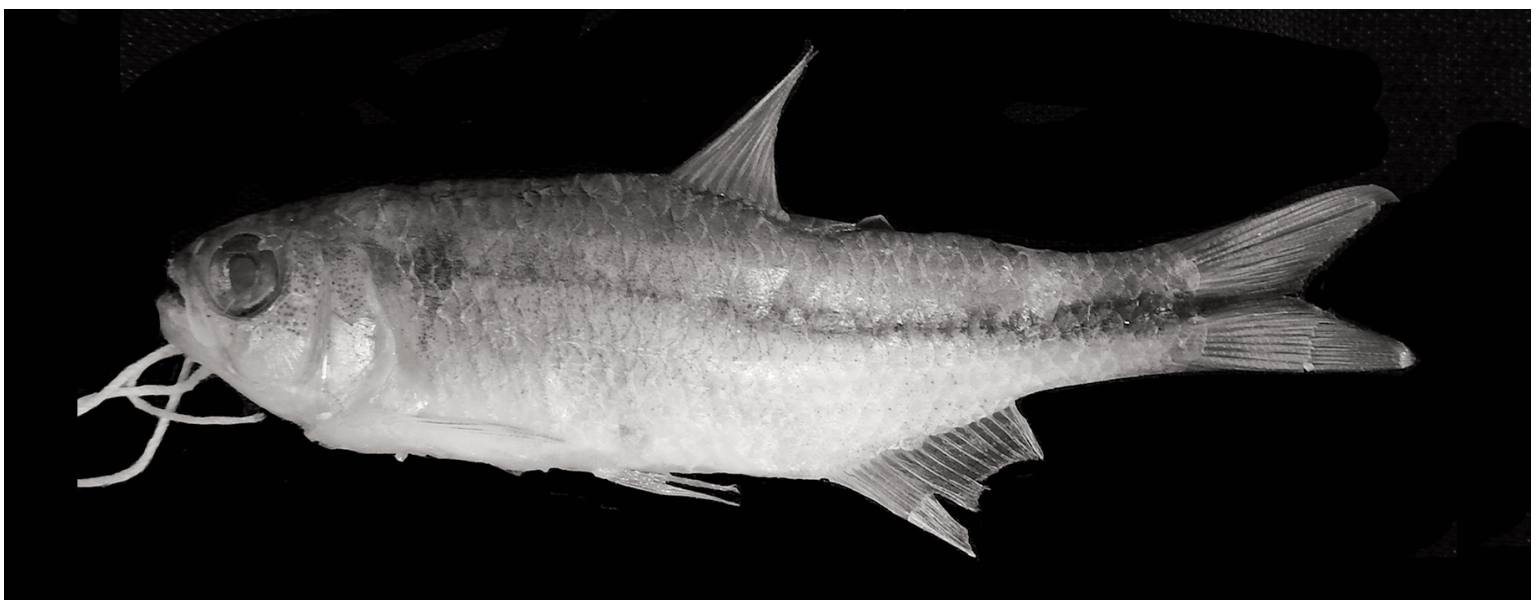

Figure 1. Sample of Astyanax rivularis (80 mm standard length).

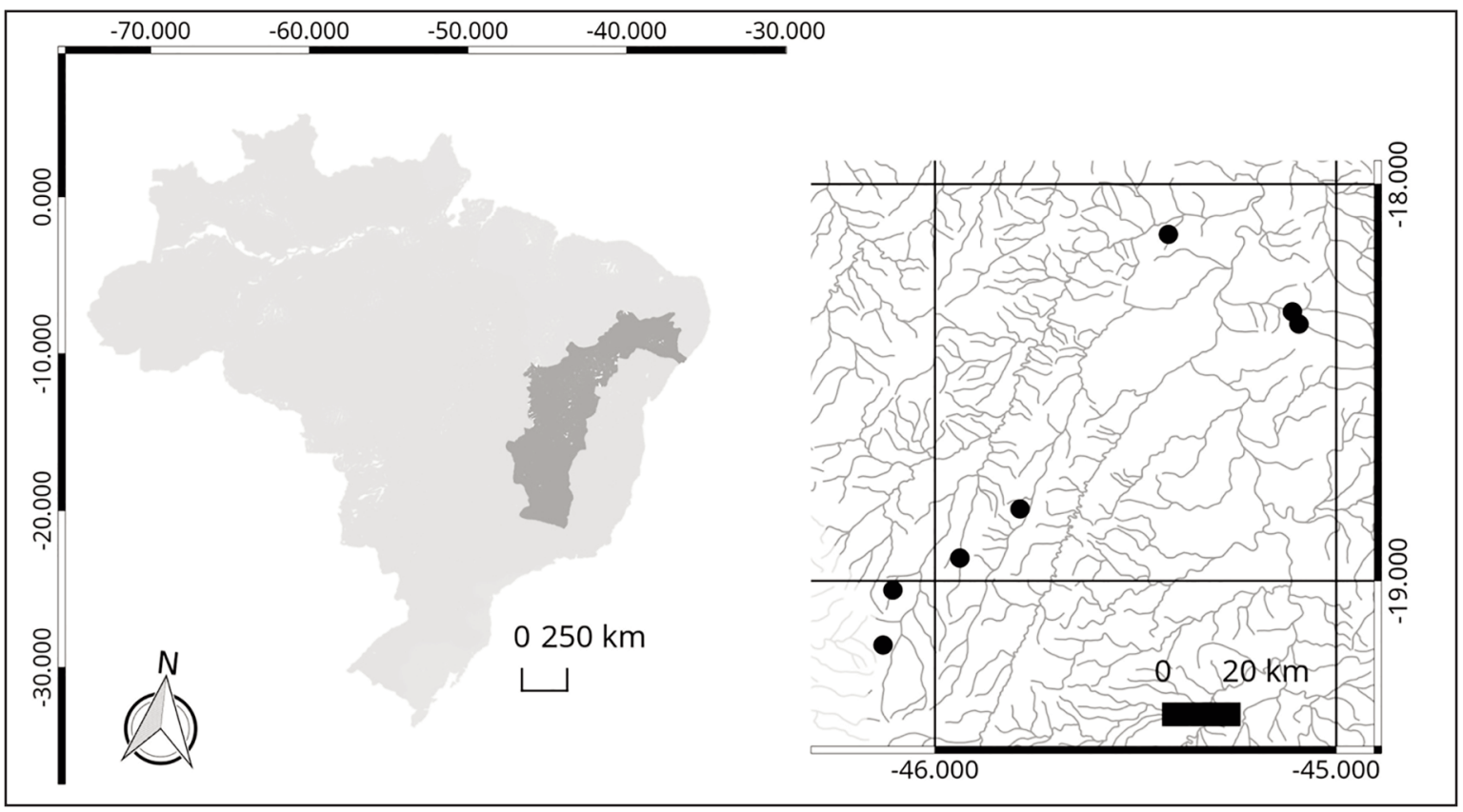

Figure 2. Map of Brazilian hydrographic basins with São Francisco river basin in dark gray (left); distribution of the samples in left tributaries of the Upper São Francisco river basin (right). 
Here we present the morphometric data of seven populations of $A$. rivularis, with the purpose to better understand the distribution and diversity of the species.

\section{MATERIAL AND METHODS}

Seven population of $A$. rivularis were sampled totaling 69 individuals collected in tributaries of the left margin of Upper São Francisco River basin (Fig. 2), increasing the range of distribution of this species to Upper São Francisco River basin. Sampling and euthanizing of specimens were carried out in accordance with the recommendations of the Conselho Nacional de Controle de Experimentação Animal (CONCEA).

The specimens were deposited in the Collection of Vertebrates of the UFV Laboratory of Ecological and Evolutionary Genetics, at Rio Parnaíba Campus - CV-LaGEEvo. The identification was made according to Britski et al. (1988) and Lütken's description. The morphometric characters were obtained in millimeters $(\mathrm{mm})$ with the help of a digital caliper with a $0.01 \mathrm{~mm}$ resolution.
All the data were obtained only from the left size of the sample considering the following measurements: standard head length, predorsal distance, prepelvic distance, preanal distance, height of dorsal origin, height of tail peduncle, length of anal basis, length of dorsal basis, length of pelvic basis, length of pectoral basis, head height, snout length, eye diameter, interorbital distance and jaw length.

\section{RESULTS}

All analyzed individuals were identified as $A$. rivularis according to available literature.

The standard length was between $41.44 \mathrm{~cm}$ to $82.73 \mathrm{~cm}$ (Tables 1 to 7 ). The highest standard length mean was found in Borrachudo stream population $(70.36 \mathrm{~cm})$, and the lowest was in Curral das Éguas stream $(44.94 \mathrm{~cm})$. The snout length and head height were the most variable characteristics, meanwhile the length of pectoral basis and the length of head were the less ones (Fig. 3). The scales in the lateral line range from 32 to 39 , and the branched anal-fin rays range from 16 to 24 (see the tables).

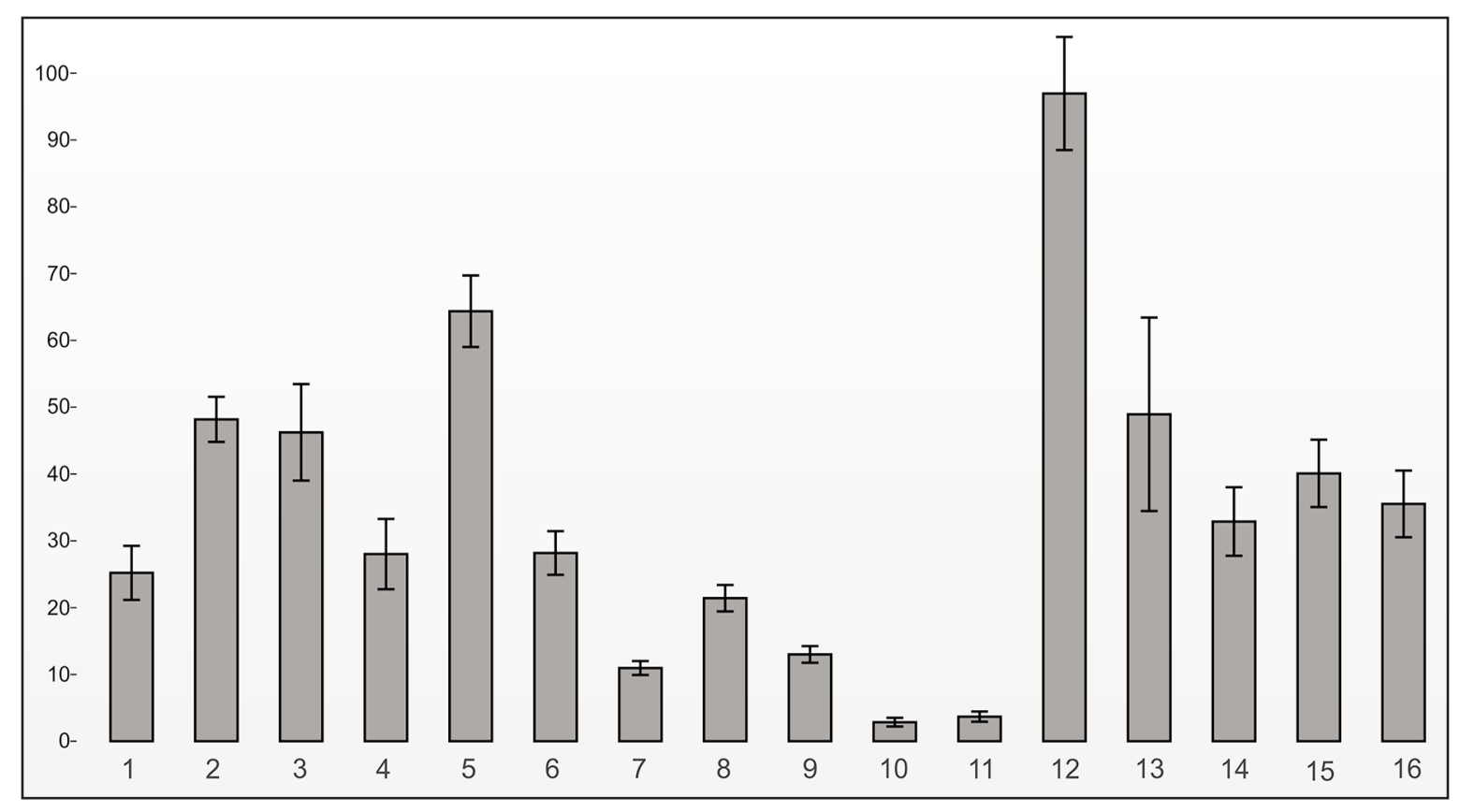

Figure 3. Graphic with mean and standard deviation of morphometric data from seven Astyanax rivularis populations. 1: predorsal distance; 2: prepelvic distance; 3: prepectoral distance; 4: preanal distance; 5: height of dorsal origin; 6: height of tail peduncle; 7: length of anal basis; 8: length of dorsal basis; 9: length of pelvic basis; 10: length of pectoral basis; 11: length of head; 12: head height; 13: snout length; 14: eye diameter; 15: interorbital distance; 16: jaw length. 


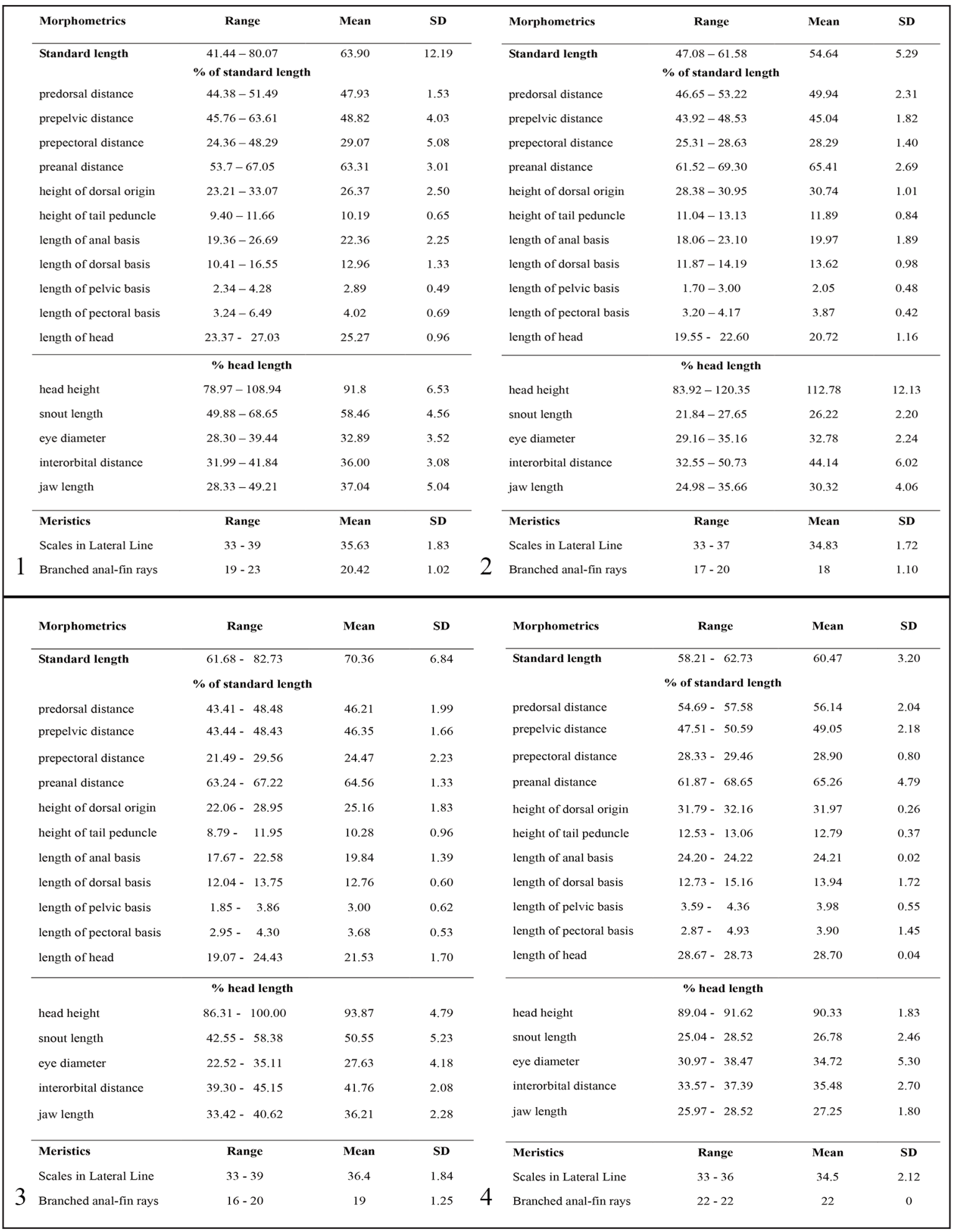

Table 1. Morphometric and meristic data from Lage stream ( $\mathrm{n}=19)$. Vouchers 1973, 1974, 1975, 1976, 1977, 1978, 1981, 1982, 1983, 1984, 1985, 1988, 1989, 1991, 1994, 2000, 2016, 2021, 2023. Table 2. Morphometric and meristic data from Açude Lote $94(n=6)$. Vouchers 2937, 2938, 2939, 2940, 2941, 2944. Table 3. Morphometric and meristic data from Borrachudo stream $(\mathrm{n}=10)$. Vouchers 2048, 2050, 2051, 2052, 2053, 2054, 2069, 2070, 2072, 2073.Table 4. Morphometric and meristic data from Vereda Grande river $(\mathrm{n}=2)$. Voucher 2226, 2230. 


\begin{tabular}{|c|c|c|c|c|c|c|c|c|}
\hline Morphometrics & Range & Mean & SD & & Morphometrics & Range & Mean & SD \\
\hline Standard length & $34.95-56.72$ & 44.94 & 9.25 & & Standard length & $49.18-69.14$ & 57.41 & 5.58 \\
\hline & $\%$ of standard length & & & & & $\%$ of standard length & & \\
\hline predorsal distance & $47.84-52.14$ & 49.85 & 1.69 & & predorsal distance & $29.82-51.47$ & 46.48 & 6.19 \\
\hline prepelvic distance & $40.69-54.18$ & 48.11 & 4.24 & & prepelvic distance & $21.43-52.88$ & 36.16 & 14.18 \\
\hline height of dorsal origin & $25.19-43.89$ & 31.28 & 5.97 & & height of dorsal origin & $25.88-29.80$ & 27.57 & 1.06 \\
\hline height of tail peduncle & $10.11-11.09$ & 10.64 & 0.33 & & height of tail peduncle & $9.83-13.91$ & 11.23 & 1.08 \\
\hline length of anal basis & $19.92-22.65$ & 21.03 & 1.03 & & length of anal basis & $17.82-23.66$ & 20.75 & 1.59 \\
\hline length of dorsal basis & $11.40-14.62$ & 12.84 & 1.27 & & length of dorsal basis & $11.57-18.18$ & 13.57 & 1.90 \\
\hline \multicolumn{4}{|c|}{$\%$ head length } & \multicolumn{5}{|c|}{$\%$ head length } \\
\hline head height & $83.07-105.22$ & 93.46 & 9.43 & & head height & $86.14-111.97$ & 99.35 & 7.49 \\
\hline snout length & $53.91-93.42$ & 62.60 & 13.79 & & snout length & $22.78-34.13$ & 28.25 & 3.87 \\
\hline eye diameter & $25.71-54.39$ & 34.38 & 9.22 & & eye diameter & $28.63-39.09$ & 34.32 & 2.87 \\
\hline interorbital distance & $33.63-43.74$ & 38.60 & 4.07 & & interorbital distance & $34.46-52.10$ & 43.15 & 7.00 \\
\hline jaw length & $31.29-40.16$ & 36.23 & 3.34 & & jaw length & $26.54-45.47$ & 36.61 & 6.99 \\
\hline Meristics & Range & Mean & SD & & Meristics & Range & Mean & SD \\
\hline Scales in Lateral Line & $30-38$ & 34.14 & 2.67 & & Scales in Lateral Line & $34-39$ & 36 & 1.94 \\
\hline
\end{tabular}

\begin{tabular}{|c|c|c|c|c|}
\hline & Morphometrics & Range & Mean & SD \\
\hline & Standard length & $56.6-73.16$ & 61.15 & 4.22 \\
\hline \multicolumn{5}{|c|}{$\%$ of standard length } \\
\hline & predorsal distance & $44.43-50.05$ & 48.02 & 1.76 \\
\hline & prepelvic distance & $45.56-52.19$ & 48.15 & 1.96 \\
\hline & prepectoral distance & $23.20-31.46$ & 26.49 & 2.16 \\
\hline & preanal distance & $63.74-68.73$ & 66.21 & 1.94 \\
\hline & height of dorsal origin & $28.83-32.39$ & 30.32 & 1.11 \\
\hline & height of tail peduncle & $10.88-12.39$ & 11.61 & 0.44 \\
\hline & length of anal basis & $18.74-24.09$ & 22.13 & 1.38 \\
\hline & length of dorsal basis & $15.47-17.20$ & 12.80 & 1.02 \\
\hline & length of pelvic basis & $1.99-3.36$ & 2.56 & 0.46 \\
\hline & length of pectoral basis & $2.87-4.81$ & 3.65 & 0.49 \\
\hline & length of head & $24.06-27.91$ & 26.22 & 1.09 \\
\hline \multicolumn{5}{|c|}{$\%$ head length } \\
\hline & head height & $98.03-114.11$ & 104.42 & 4.80 \\
\hline & snout length & $51.47-60.39$ & 55.49 & 2.77 \\
\hline & eye diameter & $28.75-51.12$ & 34.69 & 5.35 \\
\hline & interorbital distance & $38.27-47.71$ & 43.48 & 2.96 \\
\hline & jaw length & $32.34-46.03$ & 35.71 & 3.34 \\
\hline & Meristics & Range & Mean & SD \\
\hline 7 & Scales in Lateral Line & $32-38$ & 35.2 & 2.04 \\
\hline
\end{tabular}

Table 5. Morphometric and meristic data from das Éguas stream (n=7). Voucher 2169, 2170, 2172, 2172, 2173, 2175 , 2177. Table 6. Morphometric and meristic data from Tiros stream $(\mathrm{n}=10)$. Voucher 2030, 2032, 2033, 2034, 2036, 2037, 2038, 2039, 2040, 2045. Table 7. Morphometric and meristic data from do Boi river ( $\mathrm{n}=15)$. Voucher 2145, 2147, $2149,2149,2150,2152,2153,2154,2158,2159,2161$, 2163, 2164, 2165, 2166.

\section{DISCUSSION}

Here we describe morphological diversity data from seven populations of $A$. rivularis.

Our data shows that in this region there is a huge diversity in size, shape and meristic counts in this species. Besides being considered a single valid species, separeted from A. scabripinnis according to the Catalog of Fishes (Eschmeyer \& Fong, 2019), such diversity can indicate a high polymorphic species or we are dealing with a species complex.

Surveys in the Velhas River basin as a whole observed the occurrence of $A$. scabripinnis rather than A. rivularis (Alves \& Pompeu, 2005) among the 107 species in the watershed, out of the 176 
species of the São Francisco River in Minas Gerais (Alves et al., 1998, apud Alves \& Pompeu, 2005). Meanwhile, a survey in the Serra do Cipó National Park identified three species of the genus Astyanax among the 36 species of fish collected in the Cipó River basin, a tributary of the Velhas River (Vieira et al., 2005). However, the presence of $A$. rivularis or Hasemannia nana was not reported, which led Triques (2006) to record the addition of these species to the list of fishes of the Serra do Cipó National Park. It was speculated that their absence in the first list was due to one of five factors, including that such species were collected but were not taxonomically recognized (Triques, 2006). Indeed, Vieira et al. (2005) reported the presence of $A$. scabripinnis, which suggests that the authors did not consider $A$. rivularis a valid species.

Casatti \& Castro (1998) reports an occurrence of A. rivularis in the headwaters of São Francisco river. In their identification key for fishes of the São Francisco River basin, Britski and colleagues (1988) present it as A. scabripinnis rivularis, but do not record it in the list of the species found in the region of Três Marias - MG. Triques (2006) considers that, among other reasons, it is due to its absence in the region. However, there are reports from cytogenetic studies, where samples are identified as A. scabripinnis, in two populations close to the Três Marias (Minas Gerais State) region, with divergent diploid chromosome numbers $2 \mathrm{n}=46$ at Curral das Éguas populations and $2 \mathrm{n}=50$ chromosomes at Viveiro de Mudas population (Moreira-Filho and Bertollo, 1991). Also in the region of Três Marias, Souza \& Moreira-Filho (1995) identified $2 \mathrm{n}=50$ chromosomes for a population of A. scabripinnis from the Barreiro Grande Creek.

Lütken (2001) reports the morphological characteristics of $A$. rivularis, highlighting 33 to 38 lateral line scales; 5 to 6 rows of scales above the lateral line and 6 to 7 below it; on average, the number of ridged striations is high: 07-12-19 in larger specimens, 5 to 10 in smaller; $3+16$ to 21 (mean $3+18$ ) rays in the anal fin; head length contained 4 times or slightly less in standard length; height contained about 3 times in the standard length; eye diameter of 3 and $1 / 3$ to more than four times in the length of the head; The infra-or- bital bones are usually somewhat arched and wellequipped with furrowed grooves; the jawbone usually reaches up to quite below the eyes, more rarely just up the vertical line drawn from its anterior edge; there are 5 intermaxillary teeth in first series and jawbone with 1 to 3 small teeth; the dorsal fin height is generally smaller than its distance from the adipose fin; the tip of the pectoral fin never reaches the ventral fin. Lütken further comments that $A$. rivularis closely resembles $A$. fasciatus (treated by him as Tetragonopterus $\mathrm{cu}$ vieri) both in body shape and in general appearance.

Therefore, an effort from different areas of science is necessary to better characterize the natural history and geographical distribution of this species in the São Francisco basin, considering that, through DNA "barcoding" technique, Carvalho and colleagues (2011) observed only $0.93 \%$ divergence between $A$. rivularis and $A$. fasciatus Cuvier, 1819, another species that has been very difficult to classify, since it was first described in the rivers of Brazil. Besides, different chromosome numbers in the different populations studied suggest that even A. rivularis in São Francisco River (data not shown) may represent more than one Operational Taxonomic Unit, thus highlighting the need for further studies in the region.

\section{ACKNOWLEDGEMENTS}

The authors are thankful to William Lopes Silva, Rafael Henrique Fernandes, Denis Glauber da Rocha Reis, Rodrigo Desordi, and Pierre Rafael Penteado (Rio Paranaiba, MG, Brazil) for the collection of samples. This work was developed with funding provided by the Foundation for Research Support of the State of Minas Gerais (Fundação de Amparo à Pesquisa do Estado de Minas Gerais, FAPEMIG) and the Universidade Federal de Viçosa, Rio Paranaíba Campus.

\section{REFERENCES}

Alves C.B.M. \& Pompeu P.S., 2005. Historical Changes in the Rio das Velhas Fish Fauna - Brazil. In: Hughes, R.M., Rinne J.N. \& Calamusso B. (Eds.). Historical changes in large river fish assemblages of the Amer- 
icasI. Bethesda: American Fisheries Society Symposium, 45: 587-602.

Bertaco V.A. \& Lucena C.A.S., 2006. Two new species of Astyanax (Ostariophysi: Characiformes: Characidae) from eastern Brazil, with a synopsis of the Astyanax scabripinnis species complex. Neotropical Ichthyology, 4: 53-60. https://doi.org/10.1590/ S1679-62252006000100004

Bertollo L.A.C., Takahashi C.S. \& Moreira-Filho O., 1978. Cytotaxonomic considerations on Hoplias lacerdae (Pisces, Erythrinidae). Brazilian Journal of Genetics, 1: 103-120.

Britski H.A, Sato Y. \& Rosa A.B.S., 1988. Manual de identificação de peixes da região de Três Marias (com chave de identificação para os peixes da bacia do São Francisco). Brasília, Câmara dos Deputados/ Companhia do Desenvolvimento do Vale do São Francisco, Brasília, Brazil. http://trove.nla.gov.au/ work $/ 37530121$ ? selectedversion $=$ NBD45784411

Carvalho D.C., Oliveira D.A.A., Pompeu P.S., Leal C.G., Oliveira C. \& Hanner R., 2011. Deep barcode divergence in Brazilian freshwater fishes: the case of the São Francisco River basin. Mitochondrial DNA, 22(S1): 80-86. https://doi.org/10.3109/19401736. 2011.588214)

Casatti L. \& Castro R.M.C., 1998. A fish community of the São Francisco River headwater riffles, Southeastern Brazil. Ichthyological Exploration of Freshwaters, 9: 229-242.

Eigenmann C.H., 1921. The American Characidae. Part 3. Cambridge. Memoirs of The Museum of Comparative Zoology, 43: 209-310. https://doi.org/10.5962/ bhl.title.49183).

Elliot N.G., Haskard K. \& Koslow J.A., 1995. Morphometric analysis of orange roughy (Hoplostethus atlanticus) off the continental slope of southern Australia. Journal of Fish Biology, 46: 209-220. https://doi.org/10.1111/j.1095-8649.1995.tb059 62. $\mathrm{x}$

Eschmeyer W.N. \& Fong J.D., 2019. Catalog of Fishes. Acessible at http://researcharchive.calacademy.org/ research/ichthyology/catalog/SpeciesByFamily.aspx Consulted on 11th July 2019.

Garutti V., 1995. Revisão taxonômica dos Astyanax (Pisces, Characidae), com mancha umeral ovalada e mancha do pedúnculo caudal estendendo-se à extremidade dos raios caudais medianos, das bacias do Paraná, São Francisco e Amazônia. M.Sc. dissertation. São Paulo: Universidade Estadual Paulista, São José do Rio Preto. 47 pp. http://download.uft.edu.br/?d=209d4f96-239d-4143-9d9 e-8e02531da6ab:Disserta $\%$ C3\%A7\%C3\%A3o completa_Vers $\%$ C3\%A3o_p $\%$ C3\%B3s_corre $\% \mathrm{C} 3$ $\% \mathrm{~A} 7 \% \mathrm{C} 3 \% \mathrm{~A} 3 \mathrm{o} 2$
Garutti V. \& Britski H.A., 2000. Descrição de uma espécie nova de Astyanax (Teleostei: Characidae) da bacia do alto Rio Paraná e considerações gerais sobre as demais espécies do gênero na bacia. Comunicações do Museu de Ciências e Tecnologia da PUC-RS, Sér. Zoologia, 13: 65-88.

Leuzzi M.S.P., Almeida F.S., Orsi M.L. \& Sodré L.M.K., 2004. Analysis by RAPD of the genetic structure of Astyanax altiparanae (Pisces, Characiformes) in reservoirs on the Paranapanema River, Brazil. Genetics and Molecular Biology, 27: 355362. https://doi.org/10.1590/S1415-47572004000 300009

Lütken C.F., 2001. Peixes do Rio das Velhas: Uma contribuição para a Ictiologia do Brasil. In: Alves C.B.M. \& Pompeu P.S. (Eds.) Peixes do Rio das Velhas: passado e presente. Belo Horizonte, SEGRAC. cap. 2, pp. 23-164.

Moreira-Filho O. \& Bertollo L.A.C., 1991. Astyanax scabripinnis (Pisces, Characidae): um complexo de espécies. Genetics and Molecular Biology, 14: 331357.

Moysés C.B. \& Almeida-Toledo L.F., 2002. Restriction fragment length polymorphisms of mitochondrial DNA among five freshwater fish species of the genus Astyanax (Pisces, Characidae). Genetics and Molecular Biology, 25: 401-407. https://doi.org/10.1590/ S1415-47572002000400008

Orsi M.L., Carvalho E.D. \& Foresti F., 2004. Biologia populacional de A. altiparanae Garutti \& Britski (Teleostei, Characidae) do médio Paranapamena, Paraná, Brazil. Revista Brasilera de Zoologia, 21: 207-218. https://doi.org/10.1590/S0101-817520040 00200008

Paiva S.R., Dergam J.A. \& Machado F., 2006. Determining management units in southeastern Brazil: the case of Astyanax bimaculatus (Linnaeus, 1758) (Teleostei: Ostariophysi: Characidae). Hidrobiologia, 560: 393-404. https://doi.org/10.1007/s10750005-9415-1

Prioli S.M.A.P., Prioli A.J., Júlio Jr. H.F., Pavanelli C.S., de Oliveira A.V., Carrer H., Carraro D.M. \& Prioli L.M., 2002. Identification of Astyanax altiparanae (Teleostei, Characidae) in the Iguaçu river, Brazil, based on mitochondrial DNA and RAPD markers. Genetics and Molecular Biology 25: 421430. https://doi.org/10.1590/S1415-47572002000 400011

Souza I.L. \& Moreira-Filho O., 1995. Cytogenetic diversity in the Astyanax scabripinnis species complex (Pisces, Characidae) I. Allopatric distribution in a small stream. Cytologia, 6: 1-11.

Triques M.L., 2006. Adições à Ictiofauna do Parque Nacional da Serra do Cipó, Minas Gerais, Brasil 
(Teleostei, Characidae). Lundiana, 7: 73-75. http:// www.icb.ufmg.br/lundiana/full/vol712006/v7120069 .pdf

Vieira F., Santos G.B. \& Alves C.B.M., 2005. A ictio- fauna do Parque Nacional da Serra do Cipó (Minas Gerais, Brasil) e áreas adjacentes. Lundiana, 6 (Supplementum): 77-87. http://www.icb.ufmg.br/lundiana/ full/vol6sup2005/15.pdf 